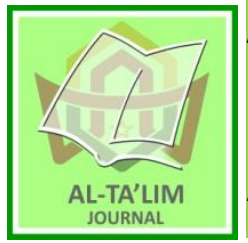

AL-TA'LIM JOURNAL, 25 (1), 2018, (56-70)

(Print ISSN 1410-7546 Online ISSN 2355-7893)

Available online at http://journal.tarbiyahiainib.ac.id/index.php/attalim

\title{
An Analysis of Managerial Competence of the Madrasah Principals in Islamic Senior High School in Tanah Datar
}

\author{
Received: $05^{\text {th }}$ April 2016; Revised: $06^{\text {th }}$ April 2016; Accepted: $19^{\text {th }}$ July 2016 \\ Permalink/DOI: http://dx.doi.org/10.15548/jt.v25i1.350
}

\begin{abstract}
Asmendri *)
Institut Agama Islam Negeri, Batusangkar, Indonesia.

E-Mail: asmendri.25@gmail.com

\section{Sufyarma Masidin}

Universitas Negeri Padang, Indonesia.

E-Mail: sufyarma@gmail.com
\end{abstract}

\section{Rusdinal}

Universitas Negeri Padang, Indonesia. E-mail: rusdinalhar@yahoo.com

\section{Mukhaiyar \\ Universitas Negeri Padang, Indonesia. E-Mail: joharmukhaiyar@gmail.com}

\section{*) Corresponding Author}

\begin{abstract}
Based on preliminary observation and research finding in MAN in Tanah Datar, it was found that madrasah which have a good accreditation still have problems concerning with aspects of school management. The purposes of this research were to analyze teachers' perception toward managerial competence of the madrasah principals in the aspects of the madrasah activities planning, organizing, leadership, actuating, and controlling. The methodology used in this research was mixed method by using the concurrent embedded model. Quantitative data was gotten from teachers of MAN in Tanah Datar while for the qualitative data was gotten from the school principals, vice school principals as well as teachers. Based on the research finding, it was found that in the madrasah activities planning was 82.11\%; activities organizing was $79.50 \%$; activities leading was $79.92 \%$; activities actuating was $78.53 \%$; and activities controlling was $81 \%$. In general, the competence of the madrasah principals of MAN in Tanah Datar was good in all aspect.
\end{abstract}

Keywords: Managerial Competence; Madrasah Principals; Islamic senior high school

How to Cite: Asmendri, A., Marsidin, S., Rusdinal, R., \& Mukhaiyar, M. (2018). An analysis of managerial competence of the madrasah principals in Islamic senior high school Tanah Datar. Al-Ta Lim Journal, 25(1). doi:http://dx.doi.org/10.15548/jt.v25i1.350

\section{INTRODUCTION}

Principal is a leadership positions that must be occupied through high consideration. Principal is a functional staff educator given the task to lead a madrasah in which organizes learning activity and promotes interaction between educators who provide lessons and learners who receive instruction. Anyone who will be appointed as principal should be determined through procedures and specific requirements such as educational background, experience, age, rank and integrity in accordance to Permendiknas No.
28 Year 2010 on Assignment of Teachers as head of school/madrasah.

Sandberg (2000); Spencer \& Spencer (2008) suggests that competence is a fixed statement of behavior that shows the results achieved in work. Anderson stated that competence consists of three components: knowledge, skills and characteristics/ behavior. They are mutually influencing the individual's behavior in implementing the tasks and improve the work of individuals and organizations. Principal competence refers to the ability or skill in carrying out duties and responsibilities as principal (Ananiadou \& 
Claro, 2009; Bolden, Gosling, Marturano, \& Dennison, 2003; De Vos, De Hauw, \& Van der Heijden, 2011; Katz, 2009; Sherehiy, Karwowski, \& Layer, 2007). A principal is certainly not enough to only understand the school vision and mission, but must have a good integrity coupled with a number of competencies required in order to carry out the duties and responsibilities as a principal properly.

Principal competences required based on Permendiknas RI No.13 of 2007 include personal, managerial, supervision, entrepreneurship, and social competence. Principal managerial competence is a set of technical skills in performing duties as manager of the madrasah to utilize all resources available to achieve the objectives effectively and efficiently (Ashlan, 2017; Kasturi, 2017; Sabandi, Anisah, \& Rusdinal, 2018; Tanjung, Azmi, \& Siahaan, 2017). According Zwell (2000), managerial competencies are competencies that relate specifically to the management, supervision and development of people.

Managerial competence is a set of technical skills that must be possessed by the principal in carrying out duties as manager. Many researches indicate that managerial competence has strong contribution to the teacher performance. Qualified teachers are determined by the principal's managerial skills. Many experts are talking about all the principal managerial skills and among of them are (Aarons, 2006; Anwar, 2003; Lunenburg \& Ornstein, 2011; Usman, 2009; Wahyudi, 2009).

Managerial skills that must be possessed by the principal are:

1) Technical skills. Technical ability is closely linked to the ability to use the tools, procedures, methods and techniques in a proper management activities (working with things).

2) Conceptual skills. Conceptual ability is mental abilities to coordinate and integrate all interests and activities of the organization. In other words, these conceptual abilities associated with the ability to create a concept (working with ideas) about various things in the institution he leads.

3) Human relationships skills. The ability of human relationships is the ability to create and maintain good relations, understanding and encouraging others so that they work voluntarily that there is no compulsion and more productive (working with people).

4) Leadership skills, namely leadership and cultural symbolic leadership. Symbolic emphasizes leadership and model implementation of staff. Cultural leadership stresses the importance of principal to believe the value and trust. All of the leadership skills required by the principal in organizing to achieve the mission and goals through consensus with teachers of madrasah.

5) Design skills. Design skills are the ability to solve problems in finding the benefits to the organization.

Murniati \& Usman (2009) also offers five types of skills required by a manager, namely: (1) cultural flexibility; (2) communication skills (3) human resources development skills; (4) creativity; and (5) self-management of learning. The areas of managerial competence of madrasah principal are related with his planning, organizing, leadership, implementation (actuating) and controlling. Certo \& Certo (2015) stated that planning is the process of determining how the organization can get where it wants to go, and what it will do to accomplish its objectives. Gomez-Mejia, Balkin, \& Cardy (2012) stated planning is a process that helps managers set objectives for the future and map out the activities and means that will make it possible to achieve those objectives. Planning is here the systematic development of madrasah action programs aimed at reaching agreed-upon madrasah objectives by the principal.

The organizing function is extremely important to the management system because it is the primary mechanism managers use to activate plans. Organizing creates and 
maintains relationships between all organizational resources by indicating which resources are to be used for specified activities and when, where, and how they are to be used. A thorough organizing effort helps managers minimize costly weaknesses, such as duplication of effort and idle organizational resources (Anggraeni, 2017; Barkah, 2017; Hapsari, 2016; Rahayu, 2016; Salim, 2017; Sodiqin \& Nurdin, 2017). Organizing in this research, madrasah principals have an obligatory to organizing academic calendar, lesson schedule, teacher tasks and madrasah activities program.

Leadership can be defined as the ability to influence the behavior and actions of others to achieve an intended purpose. Bolden \& Gosling (2006); Carroll, Levy, \& Richmond (2008); Griffin (2013) stated leadership is getting organizational members to work together to advance the interests of the organization. Miskel \& Hoy (2001) said that leadership is a process of social influence in which one person is able to enlist the aid and support of others in the accomplishment of a common task. Madrasah principal is as a teacher and staff leader has tasks (1) to communicate vision and mission of madrasah to all teachers and staffs, (2) to coordinate teachers and staffs in realization of all plans, and (3) to make team work of teachers and staffs in developing madrasah.

Implementing or actuating is fundamental function of management. Hariandja (2002) stated actuating is getting all the members of the group to want and to strive to achieve objectives of the enterprise and of the members because the members want to achieve these objectives. Actuating tasks is related with madrasah management aspects. They are management of students, teachers, staffs, finance, public relation, facilities, specific services, clerical works and curriculum and learning.

Controlling is a function on four function of management. Kerzner \& Kerzner (2017) stated that controlling is monitoring organizational progress towards goals". Hitt, Ireland, \& Hoskisson (2001) said controlling is as regulation of activities and behaviors within organization adjustment or conformity to specifications or objectives. Robbins, De Cenzo, Coulter, \& Woods (2013) also stated that the process of monitoring, comparing, and correcting work performance. All managers should control even if their units are performing as planned because they can't really know that unless they've evaluated what activities have been done and compared actual performance against the desired standard.

Relevant research shows that there are still many principals whose competences are inadequate those effects on low quality of education in general. Falender \& Shafranske, (2004, 2007) highlights many principals have lack supervision competence so that they never supervise teachers in the school. Gloria, Hird, \& Tao (2008); Pope-Davis, Toporek, \& Ortega-Villalobos (2003) also wrote that based on principal competency mapping in 31 provinces, only personal competence is above the minimum limit while others are still below. Constantine (2003); Stoltenberg (2005) shows that there are still many principals whose competences are inadequate that effects on low education quality in general. This research is about 5 principal competences (personal competence, managerial, supervision, social, and entrepreneurship) and managerial and supervision competence of the principal are still weak. The influence aspects include the mastery of science and technology, the ability to map the education problems, leadership strategies, institution maturity, internal and external collaboration, and other factors that are situated according to the characteristics of madrasah and regional policy.

Based on the studies described above and the observations done, this research focuses on the principal managerial competence in MAN Tanah Datar. Managerial competences focused in this research are related to planning, organizing, leadership, implementation (actuating) and supervision at school. These aspects are also related to the duties and functions of the 
principal. Teacher as a part of direct competence of madrasah is considered to know much about principal in carrying out her/his duties and functions in madrasah.

\section{METHOD}

The method used in this research is mixed methods research, which combines qualitative and quantitative research in order to obtain a comprehensive analysis in order to answer the research problem. The model used is a concurrent embedded model (mixed unbalanced). Creswell (2013); Sugiyono (2010) suggested that the concurrent embedded model is a combined of quantitative and qualitative method, in which the second method reinforces the first method. In this model, the use of quantitative and qualitative methods is simultaneous, but they have different potions. There is primary and secondary method. The primary method used to obtain the main data while a secondary method is used to obtain data to support the data obtained from the primary method.

\section{Population and Sample}

The population for the quantitative phase in this research is all teachers of MAN Tanah Datar. They are 188 teachers from 4 MAN in Tanah Datar. The schools are MAN 1, MAN 2, MAN 3 and MAN 4 (MAN Sumpur). The population at the qualitative phase is the principal of MAN, vice principals, and selected teachers to complete the quantitative data. The sample in this study is proportional random sampling. The goal of taking based on that sampling technique is to have balance opportunities to represent as a sample (Arikunto, 2002)

\section{Research Instruments}

The instrument used in this research is questionnaires. Questionnaires are given to teachers to obtain data on the teachers' perceptions of principal towards principal's managerial competence. Questionnaires are prepared by the following steps: (1) Determining the indicators of each sub- variables, (2) Developing grating, (3) formulateing the items, (4) Developing the instrument is complete, (5) Validating the instrument through three experts (validator), (6) Fixing the instrument corresponding to the input validator, (7) Conducting a trial questionnaire at MAN 1 Padang, and (8) Developing instrument to be used as a means of collecting data on MAN Tanah Datar. Data collection is done by visiting directly the teachers in the schools where the teachers worked in accordance with the agreed time.

Researchers explain the purpose of the study and questionnaire filling procedure. In accordance to the agreement, the investigator gave time on the same day to the respondent to complete and return the questionnaire. Based on step 5, the questionnaires used in this study are validated first. The validity of the poll taken are internal or rational validity. Sugiyono (2010) suggested that the instrument has internal validity if the criteria laid out in a rational instrument reflect what has been measured. Internal validity of the instrument in the form of non-test (questionnaire) used is sufficient to meet the construction validity.

From the instrument calculation of the 20 respondents in MAN 1 Padang which have been tested, it is known that the correlation to 14 factors (item 79 item questionnaire) can bee seen on Table 1 as follow:

Table 1. Calculation Results of Construct Validity (Item Analysis)

\begin{tabular}{|c|c|c|c|c|}
\hline No & Factor & $\begin{array}{c}\text { Count } \\
\mathrm{r}\end{array}$ & $\begin{array}{l}\text { Crite } \\
\text { ria r }\end{array}$ & $\begin{array}{l}\text { Deci } \\
\text { sion }\end{array}$ \\
\hline $\mathrm{r} 1 \mathrm{y}$ & Planning Madrasah & 0.32 & 0.30 & valid \\
\hline $\mathrm{r} 2 \mathrm{y}$ & $\begin{array}{l}\text { Developing } \\
\text { Madrasah } \\
\text { Organization }\end{array}$ & 0.85 & 0.30 & valid \\
\hline r3y & $\begin{array}{l}\text { Leading Teachers and } \\
\text { Staff }\end{array}$ & 0.75 & 0.30 & valid \\
\hline $\mathrm{r} 4 \mathrm{y}$ & $\begin{array}{l}\text { Managing Teachers } \\
\text { and Staff }\end{array}$ & 0.70 & 0.30 & valid \\
\hline $\mathrm{r} 5 \mathrm{y}$ & $\begin{array}{l}\text { Managing Madrasah } \\
\text { Infrastructure }\end{array}$ & 0.64 & 0.30 & valid \\
\hline r6y & $\begin{array}{l}\text { Managing the } \\
\text { Relationship of } \\
\text { Madrasah - Society }\end{array}$ & 0.54 & 0.30 & valid \\
\hline
\end{tabular}




\begin{tabular}{|c|c|c|c|c|}
\hline No & Factor & $\begin{array}{c}\text { Count } \\
\mathrm{r}\end{array}$ & $\begin{array}{l}\text { Crite } \\
\text { ria } r\end{array}$ & $\begin{array}{l}\text { Deci } \\
\text { sion }\end{array}$ \\
\hline r7y & Managing Student, & 0.89 & 0.30 & valid \\
\hline r8y & $\begin{array}{l}\text { Managing } \\
\text { Curriculum } \\
\text { Development }\end{array}$ & 0.89 & 0.30 & valid \\
\hline r9y & $\begin{array}{l}\text { Willing to Manage } \\
\text { Madrasah Finances }\end{array}$ & 0.78 & 0.30 & valid \\
\hline $\begin{array}{c}\mathrm{r} 10 \\
\mathrm{y}\end{array}$ & $\begin{array}{l}\text { Managing the } \\
\text { Madrasah } \\
\text { Administration }\end{array}$ & 0.70 & 0.30 & valid \\
\hline $\begin{array}{c}\mathrm{r} 11 \\
\mathrm{y}\end{array}$ & $\begin{array}{l}\text { Managing Madrasah } \\
\text { Special Unit Services }\end{array}$ & 0.70 & 0.30 & valid \\
\hline $\begin{array}{c}\mathrm{r} 12 \\
\mathrm{y}\end{array}$ & $\begin{array}{l}\text { Manage Madrasah } \\
\text { Information Systems }\end{array}$ & 0.64 & 0.30 & valid \\
\hline $\begin{array}{c}\mathrm{r} 13 \\
\mathrm{y}\end{array}$ & $\begin{array}{l}\text { Utilizing Advances in } \\
\text { Information } \\
\text { Technology }\end{array}$ & 0.59 & 0.30 & valid \\
\hline $\begin{array}{c}\mathrm{r} 14 \\
\mathrm{y}\end{array}$ & Supervising & 0.70 & 0.30 & valid \\
\hline
\end{tabular}

Based on Table 1 above, it can be seen that all items of the instrument indicators tested have good construction validity and can be used in this research. Testing instrument reliability was done through technical split (split half) and analyzed with Microsoft Excel. Testing was done by trying out the instrument once, and then the data obtained were grouped into two groups, namely the odd and even. Calculation details can be found in Appendix 3, results instrument reliability analysis is $r=0.98$ (very reliable). Based on this trial, the instrument are valid and reliable so that it can be used for measured instruments to collect the data.

Furthermore, the qualitative data was obtained by observation and interview. Researchers are direct instrument, so that the data obtained are more meaningful. Chenail (2011) suggested that researcher is the key instrument in taking qualitative data. The qualitative data related to the principal managerial competencies are the main factors affecting the managerial competence.

\section{Technique of Data Collection}

In accordance to the study design used, the data collection is done simultaneously and turned on the same day. The collection of main data was done by providing instruments to the teachers. To complete the quantitative data, the researchers conducted qualitative data collection. The sources qualitative data is any person who is considered to know about what is being asked. In this study, the main source is the principal, the vice principal, teachers, and people close to the location of the madrasah.

\section{Technique of Data Analysis}

Data analysis is an activity undertaken by researchers in analyzing the obtained data from the research (Gani \& Amalia, 2015). In accordance to the study design that is embedded concurrent models, the quantitative method is used as the primary method and qualitative method is used as a secondary method. Therefore, the analysis of the data in this study includes the analysis of quantitative and qualitative data.

Quantitative data analysis in term of teacher perception is descriptive data analysis. The analysis is done by finding the percentage of answers given to the teachers through questionnaire with the following formula:

$$
\mathrm{P}=\mathrm{x} 100 \% \cdot\left[\frac{\sum \text { score per item }}{\text { maximum score }}\right]
$$

The highest score of alternative answers to the questionnaire is 4 and the lowest is 1 . Selected category is 4 , then the length of the interval is: $\frac{4-1}{4}=3 / 4=0.75$. The interval and percentage scores can be seen in Table 5. Scores obtained for each item were compared with the ideal score, and then they were interpreted based on the scoring interpretation criteria in Table 2.

Table 2. Scoring Interpretation Criteria

\begin{tabular}{lll}
\hline $\begin{array}{c}\text { The length of } \\
\text { interval }\end{array}$ & $\begin{array}{c}\text { Percentage } \\
\text { score }\end{array}$ & $\begin{array}{l}\text { Criteria } \\
\text { Interpretation }\end{array}$ \\
\hline 0 to 1.00 & $0 \%-24 \%$ & Poor \\
1.00 to 1.75 & $25 \%-43 \%$ & Not good \\
1.76 to 2.50 & $44 \%-64 \%$ & Pretty good \\
2.60 to 3.25 & $65 \%-80 \%$ & Good \\
3.26 to 4.00 & $81 \%-100 \%$ & Very good \\
\hline
\end{tabular}




\section{RESULT AND DISCUSSION}

This research was conducted in four MAN in Tanah Datar through 128 respondents. These schools are MAN 1 with 34 respondents, MAN 2 with 48 respondents, MAN 3 with 25 respondents, and MAN 4 with 21 respondents. Quantitative data from respondents was obtained through questionnaires. Questionnaires were given to respondents consisted of 79 statements about the principal managerial competences. Qualitative data were obtained from observations and interview of principals, viceprincipals, teachers and communities around the madrasah.

Managerial competence is related to the duties and functions of the principal in planning, organizing, leading, implementing (actuating) and controlling the management aspects of the madrasah. Alternative answers provided in the questionnaire are: Strongly Agree, Agree, Disagree, and Strongly Disagree.

\section{Planning of Madrasah Program}

Principal competences on tasks and functions implementation of planning management aspect can be seen in Figure 1.

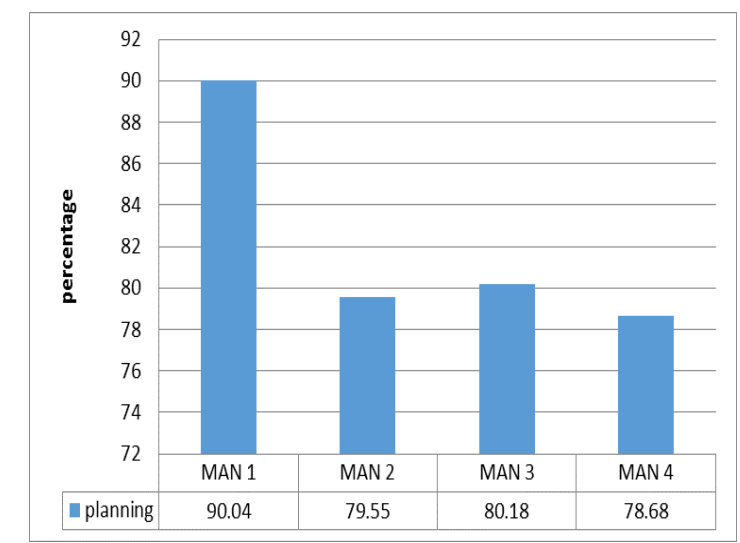

Figure 1. Principal Competence of MAN on Planning Management Aspects of Madrasah

It is shown in Figure 1 that the average competence of the principal of MAN 1 is the highest (90.04) among others and the principal of MAN 4 is the lowest (78.68). In its interpretation, the competence of principal of MAN 1 of all planning aspects is very good, while the others are good. In general in can be stated that the principal competence of the four schools in planning is very good (82.11). The score result measured by using ideal mean of ideal maximum score is shown in Table 2.

Table 2. Score of Principal Planning Competence

\begin{tabular}{|c|c|c|}
\hline No & Commentary & Result \\
\hline 1 & Number of Respondents & 128 \\
\hline 2 & $\begin{array}{l}\text { Number of items of planning } \\
\text { aspects }\end{array}$ & 11 \\
\hline 3 & Achieved Score & 4636 \\
\hline 4 & Ideal Maximum Score & 5632 \\
\hline 5 & Ideal Mean (Mi) & 2816 \\
\hline 6 & Sdi & 938.67 \\
\hline \multirow{7}{*}{7} & Depth Category & \\
\hline & - Very Good / Very High = X> & $X>$ \\
\hline & $\mathrm{Mi}+2,25 . \mathrm{Sdi}$ & $\begin{array}{l}4928 \\
4224 \leq\end{array}$ \\
\hline & $\begin{array}{l}\text { - Good } / \text { High }=\mathrm{Mi}+1,5 . \mathrm{Sdi} \leq \mathrm{x} \\
\quad \leq \mathrm{Mi}+2,25 . \mathrm{Sdi}\end{array}$ & $\begin{array}{c}x \leq \\
4928 \\
3520\end{array}$ \\
\hline & $\begin{array}{l}\text {-Pretty Good / Medium = Mi + } \\
\text { 0,75.Sdi } \leq \mathrm{x} \leq \mathrm{Mi}+1.5 . \mathrm{Sdi}\end{array}$ & $\begin{array}{c}\leq X> \\
4224.01 \\
2816 \leq\end{array}$ \\
\hline & $\begin{array}{l}\text { - Not Good } / \text { Low }=\text { Mi Mi }+\leq x \\
\leq 0.75 . \mathrm{Sdi}\end{array}$ & $\begin{array}{c}x \leq \\
3520 \\
X\end{array}$ \\
\hline & $\begin{array}{l}\text { - Poor / Very low }=\mathrm{X}<\mathrm{Mi} \\
\text { Conclusion }\end{array}$ & $<2816$ \\
\hline 8 & $\begin{array}{l}\text { The score }(4636) \text { ranges } \\
\text { between } 4224-4928\end{array}$ & $\begin{array}{l}\text { High } \\
\text { category }\end{array}$ \\
\hline
\end{tabular}

Table 2 shows that the achieved score based on teacher perception by the principal of MAN Tanah Datar is 4636. The ideal maximum score is obtained by multiplying 128 (number of respondents) x 11 (number of questions for the planning aspects) $\mathrm{x} 4$ (the highest score each question). The obtained ideal scores is 5632. Because the score achived is 4636 (between $4224(\mathrm{Mi}+1,5 . \mathrm{Sdi})$ and 4928 ( $\mathrm{Mi}+2,25$. Sdi value), then the competence of the head of MAN in the Tanahdatar on planning aspects is categorized into high category.

\section{Organizing Madrasah Program}

The average of teacher perception of principal competence on this aspect can be seen in Figure 2. 


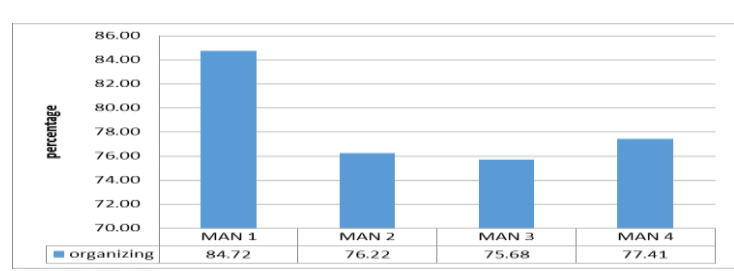

Figure 2. Principal Competence in Organizing

Figure 2 show that the competence of the head of MAN 1 is the highest (88.11). The lowest competence is achieved by the head of MAN 3 (73.67). The interpretation through scoring criteria in Table 5 shows that the principal of MAN 1 is very good, while the principal of MAN 2, MAN 3, and MAN 4 are good. In general, the competence of MAN principals in Tanah datar based on this aspect is good (79.50). The score result measured by using ideal mean of ideal maximum score is shown in Table 3.

Table 3. Score of Principal Competence on Organizing Aspect

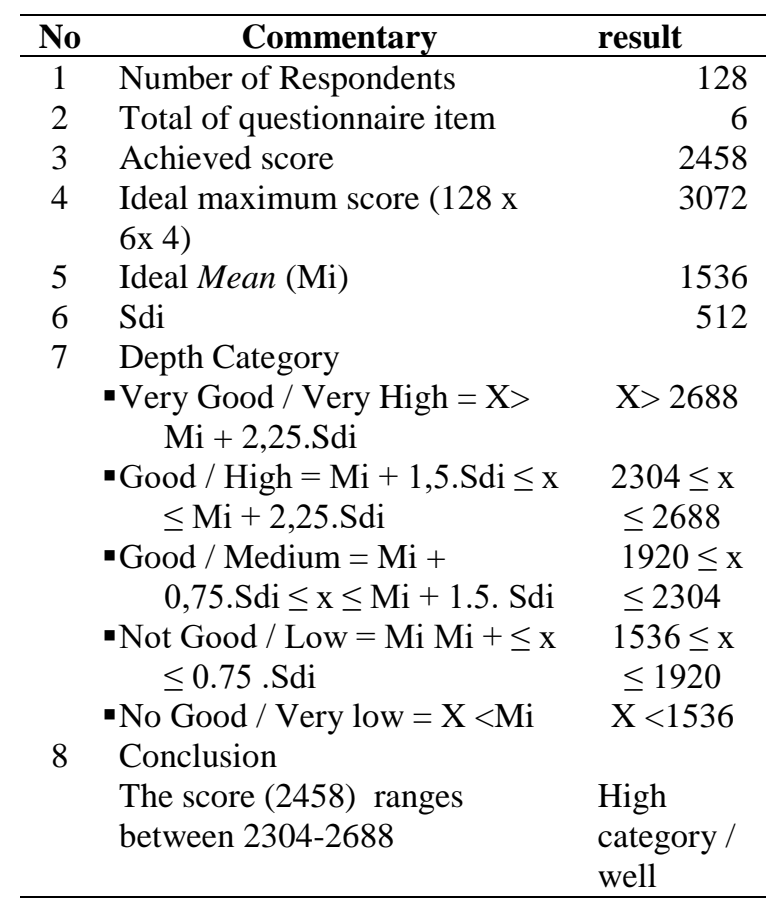

Table 3 shows that the achievement of competence of principals of MAN Tanahdatar based on perceptions is 2458. The ideal maximum score is 3072 . Because 2458 is between $2304(\mathrm{Mi}+1$,5.Sdi) and 2304 (value $\mathrm{Mi}+2.25$. Sdi), the principal competence of MAN in Tanahdatar on organizing aspects is in high category.

\section{Leading Madrasah Program}

The average of teachers' perception on leadership aspects can be seen in Figure 3.

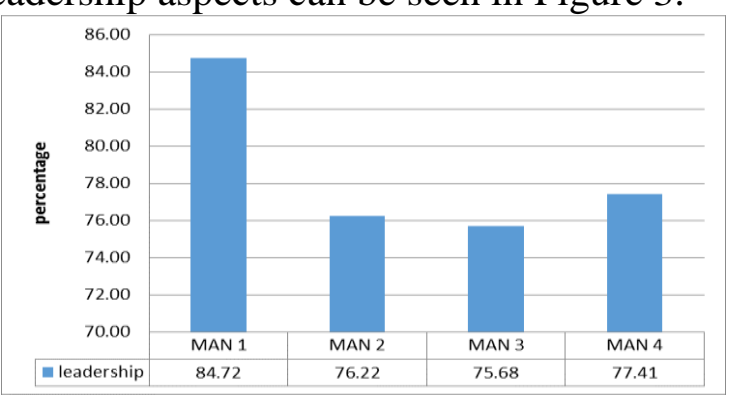

Figure 3. Competence principal on leadership aspect

It can be seen from the figure that the principal leadership competence of MAN 1 is very good (89.25), while the other principals are good. If interpreted through scoring criteria on Table 3, the principal competence in leadership aspect is good (79.92). The score result measured by using ideal mean of ideal maximum score is shown in in Table 14.

Table 4. Principal Leadership Competence

\begin{tabular}{|c|c|c|}
\hline NO & Commentary & Result \\
\hline 1 & Number of Respondents & 128 \\
\hline 2 & $\begin{array}{l}\text { Total of questionnaire item of } \\
\text { aspects }\end{array}$ & 8 \\
\hline 3 & Achieved score & 3292 \\
\hline 4 & Ideal maximum score $(128 \times 8 \times$ & 4096 \\
\hline 5 & Ideal Mean (Mi) & 2048 \\
\hline 6 & Sdi & 682.67 \\
\hline \multirow[t]{8}{*}{7} & Depth Category & \\
\hline & $\begin{array}{l}\text { Very Good / Very High }=\mathrm{X}>\mathrm{Mi} \\
+2,25 . \text { Sdi }\end{array}$ & $X>3584$ \\
\hline & Good $/$ High $=$ Mi $+1,5$. Sdi $\leq x \leq$ & $3072 \leq x \leq$ \\
\hline & $\mathrm{Mi}+2,25 . \mathrm{Sdi}$ & 3584 \\
\hline & Good $/$ Medium $=\mathrm{Mi}+$ 0,75.Sdi $\leq$ & $\leq \leq X 2560$ \\
\hline & $\mathrm{x} \leq \mathrm{Mi}+1.5 . \mathrm{Sdi}$ & 3072 \\
\hline & $\begin{array}{l}\text { Not Good } / \text { Low }=\text { Mi Mi }+\leq x \leq \\
0.75 \text {.Sdi }\end{array}$ & $\begin{array}{c}2048 \leq x \leq \\
2560\end{array}$ \\
\hline & No Good / Very low $=\mathrm{X}<\mathrm{Mi}$ & $X<2048$ \\
\hline \multirow[t]{2}{*}{8} & Conclusion & \\
\hline & The score (3292) ranges between & $\begin{array}{l}\text { High } \\
\text { category }\end{array}$ \\
\hline
\end{tabular}

Table 4 shows that the principal competence of MAN Tanah Datar based on the teacher perception is 3292. ideal The maximum score is 4096. Because it ranges between $3072(\mathrm{Mi}+1$,5.Sdi) and 3584 (value $\mathrm{Mi}+2,25 . \mathrm{Sdi})$, the competence of the 
principal of MAN Tanah Datar on leadership aspect is high category.

\section{Implementation of Madrasah program}

The average of teacher perception of principal managerial competence on organizing aspects can be seen in Figure 4.

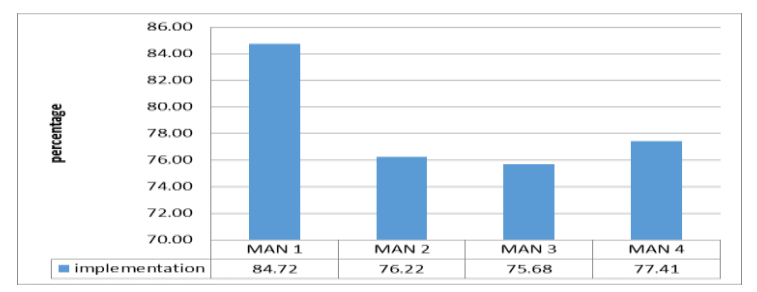

Figure 4. Principal Competence on the implementation /management aspects

Figure 4 above shows that the score achieved by principal of MAN 1 is very good $(84,72)$, while the others are good. If interpreted by using score criteria on Table 3, then the general principal competence in term of implementation is good $(78,53)$. The score result measured by using ideal mean of ideal maximum score is shown in Table 5.

Table 5. Principal management competence on implementation aspects

\begin{tabular}{|c|c|c|}
\hline No. & Commentary & Result \\
\hline 1 & $\begin{array}{l}\text { Number of Respondents } \\
\text { Total questionnaire item of } \\
\text { implementation }\end{array}$ & 128 \\
\hline 2 & management aspects & 48 \\
\hline 3 & $\begin{array}{l}\text { Achieved score } \\
\text { Ideal maximum score }(128\end{array}$ & 19354 \\
\hline 4 & $\mathrm{X} 48 \times 4)$ & 24576 \\
\hline 5 & Ideal Mean (Mi) & 12288 \\
\hline 6 & $\begin{array}{l}\text { Sdi } \\
\text { Depth Category } \\
\square \text { Very Good / Very High }= \\
\mathrm{X}>\mathrm{Mi}+2,25 . \mathrm{Sdi} \\
\square \text { Good } / \text { High }=\mathrm{Mi}+ \\
1,5 . \mathrm{Sdi} \leq \mathrm{X} \leq \mathrm{Mi}+2,25 . \mathrm{Sdi}\end{array}$ & $\begin{array}{l}X>21504 \\
\leq x \leq 18 \\
43221504\end{array}$ \\
\hline 7 & $\begin{array}{l}\square \text { Good } / \text { Medium }=\mathrm{Mi}+ \\
0,75 . \mathrm{Sdi} \leq \mathrm{x} \leq \mathrm{Mi}+1.5 . \mathrm{Sdi} \\
\square \text { Not Good } / \text { Low }=\mathrm{Mi} \mathrm{Mi} \\
+\leq \mathrm{x} \leq 0.75 . \text { Sdi } \\
\square \mathrm{No} \text { Good } / \text { Very low }=\mathrm{X} \\
<\mathrm{Mi} \\
\text { Conclusion }\end{array}$ & $\begin{array}{l}\leq 1843215 \\
360 \leq X \\
12288 \leq x \leq \\
15360 \\
X<12288\end{array}$ \\
\hline 8 & $\begin{array}{l}\text { The score (19354) ranges } \\
\text { between } 18432-21504\end{array}$ & $\begin{array}{l}\text { High } \\
\text { category / } \\
\text { well }\end{array}$ \\
\hline
\end{tabular}

Table 5 above shows that the achieved score of principals of MAN Tanahdatar based on teacher perception is 19354. The ideal maximum score is 24576. Because it ranges between $18432(\mathrm{Mi}+1,5 . \mathrm{Sdi})$ and 21504 (value $\mathrm{Mi}+2,25 . \mathrm{Sdi}$ ), the competence is good /high. The detail aspects of principal managerial competence are shown in Figure 5.

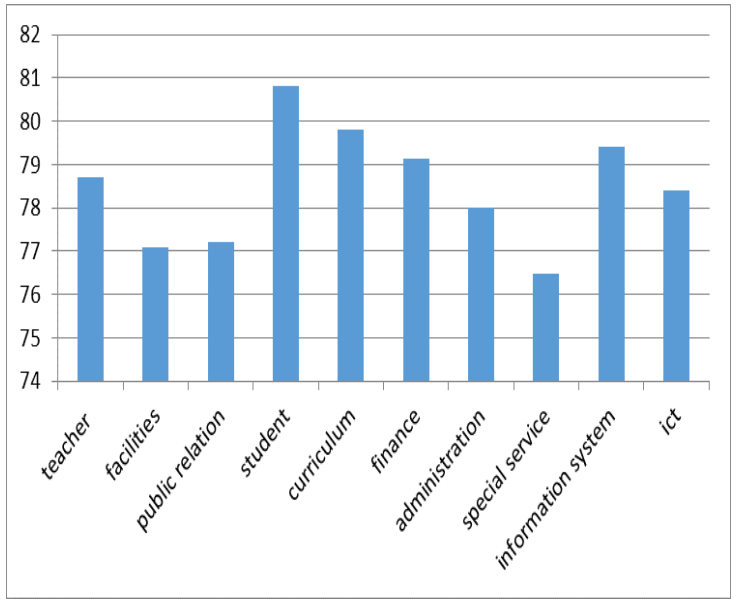

Figure 5. Principal Competence on Implementation/Management Aspects

Figure 5 shows the average teacher perception on principal competence in organizing madrasah. The overall competence is below 80 . The highest score is on aspect of student and the lowest score is on facilities aspect, public relation and special services.

\section{Controling Madrasah Program}

Perception analysis of principal managerial competence of MAN on monitoring aspect can be seen in Figure 6 .

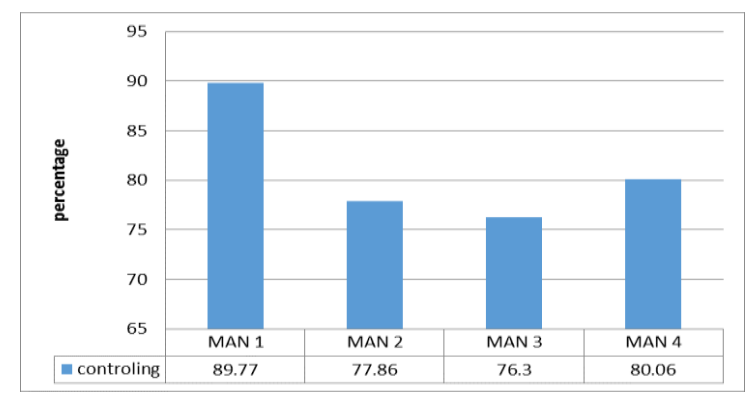

Figure 6. Principal competence on controlling management aspect 
Figure 6 shows that the principal competence of MAN 1 in this aspect is very good (89.77), while the three others are good. The overall score is good based on the interpretation through scoring criteria on Table 3. The achieved score measured by using ideal mean of ideal maximum score is shown in Table 16.

Table 6. Principal Competence on Controlling Aspect

\begin{tabular}{|c|c|c|}
\hline No & Commentary & Result \\
\hline 1 & $\begin{array}{l}\text { Number of Respondents } \\
\text { Total item questionnaire }\end{array}$ & 128 \\
\hline 2 & aspects of monitoring & 6 \\
\hline 3 & $\begin{array}{l}\text { Achievement score } \\
\text { Ideal maximum score }(128 \mathrm{x}\end{array}$ & 2449 \\
\hline 4 & $6 x 4)$ & 3072 \\
\hline 5 & Mean ideal (Mi) & 1536 \\
\hline 6 & Sdi & 512 \\
\hline 7 & $\begin{array}{l}\text { Depth Category } \\
\text { - Very Good / Very High }= \\
\mathrm{X}>\mathrm{Mi}+2,25 . \mathrm{Sdi} \\
\text { - Good / High }=\mathrm{Mi}+1,5 . \mathrm{Sdi} \\
\leq \mathrm{x} \leq \mathrm{Mi}+2,25 . \mathrm{Sdi} \\
\text { - Good / Medium }=\mathrm{Mi}+ \\
\text { 0,75.Sdi } \leq \mathrm{x} \leq \mathrm{Mi}+1.5 . \mathrm{Sdi} \\
\text { - Not Good / Low }=\mathrm{Mi} \mathrm{Mi}+ \\
\leq \mathrm{x} \leq 0.75 \text {.Sdi } \\
\text { - No Good / Very low }=\mathrm{X} \\
\quad<\mathrm{Mi}\end{array}$ & $\begin{array}{c}X>2688 \\
2304 \leq x \\
\leq 2688 \\
1920 \leq \\
x \leq 2304 \\
1536 \leq x \\
\leq 1920 \\
X<1536\end{array}$ \\
\hline 8 & $\begin{array}{l}\text { Conclusion } \\
\text { The score (2449) ranges } \\
\text { between } 2304-2688\end{array}$ & $\begin{array}{l}\text { High } \\
\text { category }\end{array}$ \\
\hline
\end{tabular}

It can be seen from Table 6 that the the achieved score of principal of MAN Tanah Datar is 2449. The ideal maximum score is 2072. Because it ranges between $2304(\mathrm{Mi}+$ 1,5.Sdi) and 2688 (value $\mathrm{Mi}+2,25 . \mathrm{Sdi}$ ), the overall pricipal competence on this aspect is high/good.

Based on interviews and observation in term of management aspects, the qualitative data shows that the teachers of MAN 1 Tanah Datar have done teaching activities in appropriate competence defined in the particular semester. The appointment of teachers and education personnel is still based on the proximity to the principal. There are also teachers who do not teach discipline and make incomplete learning device. This finding has been supervised by the principal.
Another problem faced by teachers is difficulties to be promoted. The obstacles are scientific papers and completeness of the materials to be promoted. Facilities and infrastructure in these madrasahs are largely complete, although the library is still lack of books. Facilities and infrastructure completeness at the school are supported by the good cooperation of madrasah, community and alumni. The good relationship supports MAN 1 financially in any program implementation. The school is among the favourite so that there is no problem in recruiting new students.

The findings on MAN 2 Tanah Datar show that the teachers have done teaching in accordance to the competence defined at the beginning of the semester. The appointment of teachers and education personnel is still based on the proximity to the principal thus their teaching performance is not really good. Principal has been supervising the teachers related to teaching and learning devices in the classroom. To meet the promotion requirements, the principal ordered the administration staff to prepare any related materials. MAN 2 owns more complete infrastructure than the other madrasahs, but only few teachers use good media in the classroom. This schools among of the favourite in Tanah Datar. Community participation (parents and alumni) are already good that any programs are supported well financially.

There are are several findings in MAN 3 Tanah Datar. Good communication among the principals, teachers and society has not been established well. The principal tends to provide teaching assignments to teachers without being communicated in advance, so that some teachers do not teacher on their major. The principal has appointed assessor for each subject, but teachers are not ready to be supervised mainly concerned with learning media. Facilities are still not sufficient, resulting one room is used for 2 activities, such as BK services performed in the library. Relationship with the surrounding community has not been good so many madrasahs 
program has not supported well by the society such as enrolling students to this school, attending school program and school expansion. Madrasah is also difficult to find external funding to support school facilities and teachers' salaries.

The findings of MAN 4 shows that the recruitment of teachers and educational personnel is not fairly well thus it effects on their teaching performance. Training is not provided well for the teachers especially for religion teacher. There is still lack facility that special service program cannot be implemented properly. Fortunately, the principal could establish good cooperation with the surrounding society particularly for the expansion and construction of madrasah. Principals have promoted the schools to Madrasah Tsnawiyah, the context of new admissions. But because of its location is away from the crowds, schools are quiet enthusiasts.

The findings of this study confirm that the function of planning and managerial activities such as organizing, leadership and controlling are interrelated, interdependent and interacting. Planning and estimates show the proper way on how to organize any resources of the organization to achieve the highest effectiveness. Planning has close links to leadership. Planning determines the best steps to be undertaken. To make it happen, a good leader is required to direct, influence and motivate all existing resources of madrasahs. In carrying out the management aspects planned, controlling is needed so that all activities can be run as expected.

Management process starts from planning and decision-making on the various activities related to education in school administration. The next step is organizing. They are grouping and structuring the duties and responsibilities of each individual in the madrasah. The next step is the implementation of various activities as planned. Leadership is needed to move all the components so that the defined goals can be achieved. Principal mobilizes all stakeholders so that all activities can be carried out as planned in its implementation, the principal managerial competence and skills principal.

This finding is in line with Iskandar (2013) that stated that the principal must have managerial competencies to plan and manage all aspects of the madrasah (personnel, students, facilities, curriculum, etc.). He/she must be anticipative, responsive and adaptive to developments and organizational change, the ability to realize the roles in monitoring, supervision, and reporting of madrasah program implementation.

Principal as a manager must understand and know the management activities of the madrasahs. He/ she should be able to direct the various activities/ efforts towards the achievement of madrasahs objectives, to plan, to combine, to coordinate, to mobilize, and to control all existing resources effectively and efficiently (Winterton \& Winterton, 2002).

Principal Managerial competence is also associated with a set of technical skills that must be possessed by the principal in carrying out duties as manager of the madrasahs to utilize all the resources available to achieve the objectives of madrasah effectively and efficiently. Those technical skills are required to coordinate and communicate with all parties so that all school management aspects could be implemented.

Rivai \& Murni (2016); Veithzal \& Murni (2009) suggested that coordination is an activity to bring people, materials, thoughts, techniques and objectives into a harmonious and productive relationship in achieving a goal. This coordination is necessary to overcome the limits and boundaries of planning personnel to cope with the possibility of duplication in the task, the struggle for rights and responsibilities, an imbalance in the severity of the job, the crux of the run the tasks and duties and so on. Communication is the activity of spreading and conveying ideas to the rest of the organizational structure. This communication process is to channel the thoughts, ideas and intentions verbally or in writing. Communication must consider the factors that 
may affect the result of communication itself, such as situational factors (objective and subjective), teachers need, or public demand for madrasahs, and personal expectations of society.

It can be argued that the principal of MAN 1 is successful in implementing the domains of madrasah management aspects related to good planning, leadership and controlling at the madrasah. He can establish a good cooperation and communication with teachers, staff, stakeholders, and the communities that exist around the madrasah. Through coordination and good communication, any planned programs can be performed well, although not all of them done. But with good leadership, all of the components in MAN 1 move together to implement the aspects of management at the school. The low competences of the principal of MAN 3 and MAN 4 in carrying out the domains of madrasah management aspects is related to communication management in channeling the thoughts, ideas and planned to teachers, staff, stakeholders, and the society. Management aspects of planning, organizing, and controlling cannot be done well if the leader's communication is not good.

Related to principal as leader, Q.S in AlMaidah Chapter 51 says that:

$$
\begin{aligned}
& \text { يا أيها الذين آمنو ال التخذوا اليهود و النصارى }
\end{aligned}
$$

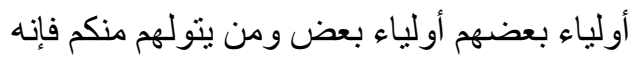

$$
\begin{aligned}
& \text { 5نهم إن الله لا يهدي القوم الظالمين - } 51
\end{aligned}
$$

Meaning: O you who believe! Ye shall not make Jews and the Christians as a loyal friend $(\mathrm{mu})$; they protect one another. Whoever among you who make them loyal friend, and then surely he belonged to them. Indeed, Allah does not guide the unjust people. (QS.5, Al-Maidah: 51)

Principal is the leader that must hold the mandate to teachers, students and the community madrasah. This can be understood in Q.S An-Nisa: 58 which mean as follows:
"Truly, God told you to convey the message to those who deserve it, and if you set the law among men should you set them fairly. Indeed, Allah is the best-giving teaching you. Indeed, Allah is Hearing, All-Seeing " (Surah Annisa: 58).

\section{CONCLUSION AND RECOMMENDATION}

The results of this research show that there are some aspects that need to be addressed by the principal in implementing management aspects in madrasah. In general the competencies on the aspects of the implementation of the least are the infrastructure management, public relation and special service unit. This suggests the need for efforts to improve the principal competence of the madrasah on this aspect. The success of principal of MAN 1 Batusangkar in the implementation of the management in the madrasah is associated with good planning, organizing, and leadership in madrasah. All will be accomplished better if the principal has the ability of good communication with all parties involved

Related to these findings, there is a need for the efforts of the Ministry of Religious Affairs of West Sumatra in this field is Madrasah Education Division to take policy in madrasah principal competency improvement especially on the low competency aspects. The effort to raise the principal managerial competence of MAN Tanahdatar theoretically can be done through analyzing the principal communication skills. All programs planned by the principal will run if community support is available.

The implementation of madrasah management is also associated with the planning and the leadership of the principal. If the planning program and the leadership are good then the management implementation will be accomplished. The skills to communicate, program planning, leadership and supervision school principals need to 
get attention in term to increase principal managerial competence.

The policy that can be implemented is the appointment to be a principal must meet the requirements, regulations and considereration of his/her managerial competence. The main point is the skill to communicate within the organization, the competence to draw up madrasah strategic planning, leadership competence and controlling.

Developing principal competence should be done through the assessment and the professional construction by credible team expertises. Furthermore, it can be done through training, seminar and others related ptograms oriented to increase the principal managerial competence. The main competence to foster is communication skills in the organization, madrasah planning competence and leadership competence.

The practical implications of this research are the appointment of a person as a candidate for the principal must be through a good selection in accordance with the applicable rules. This research also implicates that experienced principals can be trained more intensively to improve their communicative skills, competence to draw up madrasah strategic planning and leadership competence.

Four main competences of the principals of MAN Tanah Datar in general are good. The low aspect is on the implementation of the management in the madrasah and the lowest are in the aspects of infrastructure, public relation and special service. To improve the competence, the principals of MAN must have good communication skills with teachers, employees and the outside community of madrasah because school need to be supported by surrounded society particularly in funding. Government aid, in this term is DIPA, is not sufficient cover all of the needs.

The principal is a sole leader in the madrasah. He/she must be aware that his/her success depends on others, such as teachers and education personnel. The principals are expected to have responsibility to teach and affect all those involved in educational activities, especially in the implementation of the madrasah management aspects to cooperate to achieve the goals.

The principals of MAN Tanah Datar are expected to have competence to manage infrastructure and madrasah special services effectively. He/ she needs to be trained related to planning, procurement, monitoring, inventory storage and removal, as well as the competence of this arrangement are the lowest in the study's findings. They are expected to set up and maintain the existing infrastructure to contribute optimally on educational process as well as to create a clean, tidy, beautiful and fun environment for teachers and learners.

There are some suggestions for the head of Ministry of Religious Affairs Regional Office of West Sumatra and Head of Madrasah Education and other related fields: (1) the appointment of principal must meet the applicable rules by considering experience and professional aspects, (2) there must be programs to increase principal managerial competence in terms of madrasah organizational communication, madrasahs strategic planning and leadership, (3) to provide more autonomy to proposed funding support (DIPA) to the construction and development of madrasah.

For the Head Office of MORA of Tanah Datar and related fields, good supervision must be done to the principals of MAN to increase their competence. IAIN Batusangkar as the only Institutes of Islamic Religious Affairs (PTKIN) in Tanah Datar must take parts by doing many research activities and community service to MAN in Tanah Datar. Other programs associated with improving the quality of madrasahs can be training and seminars to improve teacher and principal competence. 


\section{REFERENCES}

Aarons, G. A. (2006). Transformational and transactional leadership: Association with attitudes toward evidence-based practice. Psychiatric Services, 57(8), 1162-1169.

Agung Iskandar, Y. (2013). Pengembangan Pola Kerja Harmonis Dan Sinergis, Antara Guru, Kepala Sekolah, dan Pengawas. Jakarta: PT. Bestari Buana Murni. Edisi Pertama.

Ananiadou, K., \& Claro, M. (2009). 21st century skills and competences for new millennium learners in OECD countries.

Anggraeni, A. D. (2017). Pengaruh persepsi atas kemampuan manajerial kepala sekolah dan budaya organisasi Terhadap kinerja guru. Faktor Jurnal Ilmiah Kependidikan, 4(3), 251-264.

Anwar, M. I. (2003). Administrasi Pendidikan dan Manajemen Biaya Pendidikan. Bandung: Alfabeta.

Arikunto, S. (2002). Prosedur Suatu Penelitian: Pendekatan Praktek. Edisi Revisi Kelima. Jakarta: Rineka Cipta.

Ashlan, S. (2017). Implementing the teaching supervision by principals in improving the performance of teachers in Aceh Besar. Jurnal Ilmiah Peuradeun, 5(1), 25-36.

Barkah, J. (2017). Meningkatkan kinerja guru melalui kemampuan manajerial kepala sekolah dan iklim organisasi di madrasah. Sosio E-Kons, 6(1).

Bolden, R., \& Gosling, J. (2006). Leadership competencies: time to change the tune? Leadership, 2(2), 147-163.

Bolden, R., Gosling, J., Marturano, A., \& Dennison, P. (2003). A review of leadership theory and competency frameworks. Centre for Leadership Studies, University of Exeter.

Carroll, B., Levy, L., \& Richmond, D. (2008). Leadership as practice: Challenging the competency paradigm. Leadership, 4(4), 363-379.

Certo, S. C., \& Certo, S. T. (2015). Modern Management: Concepts and Skills. Prentice Hall.

Chenail, R. J. (2011). Interviewing the investigator: Strategies for addressing instrumentation and researcher bias concerns in qualitative research. The Qualitative Report, 16(1), 255.

Constantine, M. G. (2003). Multicultural competence in supervision. Handbook of Multicultural Competencies in Counseling and Psychology, 383-391.

Creswell, J. W. (2013). Research design: Qualitative, quantitative, and mixed methods approaches. Sage publications.

De Vos, A., De Hauw, S., \& Van der Heijden, B. I. (2011). Competency development and career success: The mediating role of employability. Journal of Vocational Behavior, 79(2), 438-447.

Falender, C. A., \& Shafranske, E. P. (2004). Clinical supervision: A competencybased approach.

Falender, C. A., \& Shafranske, E. P. (2007). Competence in competency-based supervision practice: Construct and application. Professional Psychology: Research and Practice, 38(3), 232.

Gani, I., \& Amalia, S. (2015). Alat analisis data: Aplikasi Statistik untuk Penelituan Bidang Ekonomi dan Sosial. Penerbit Andi.

Gloria, A. M., Hird, J. S., \& Tao, K. W. (2008). Self-reported multicultural supervision competence of White predoctoral intern supervisors. Training and Education in Professional Psychology, 2(3), 129.

Gomez-Mejia, L. R., Balkin, D. B., \& Cardy, R. L. (2012). Management: People, Performance. Change. Boston, MA: Prentice Hall. 
Griffin, R. W. (2013). Fundamentals of management. Cengage Learning.

Hapsari, G. E. (2016). Kemampuan manajerial kepala sekolah dalam peningkatan efektivitas perpustakaan sekolah.

Hariandja, M. T. E. (2002). Manajemen sumber daya manusia. Grasindo.

Hitt, M. A., Ireland, R. D., \& Hoskisson, R. E. (2001). Manajemen Strategis Daya Saing dan Globalisasi. Edisi Pertama, Salemba Empat, Jakarta.

Kasturi, K. (2017). Madrasah Tsanawiyah principal competency-based supervision management model. Dinamika Pendidikan, 12(2), 29-39.

Katz, R. L. (2009). Skills of an effective administrator. Harvard Business Review Press.

Kerzner, H., \& Kerzner, H. R. (2017). Project management: a systems approach to planning, scheduling, and controlling. John Wiley \& Sons.

Lunenburg, F., \& Ornstein, A. (2011). Educational administration: Concepts and practices. Nelson Education.

Miskel, C. G., \& Hoy, W. K. (2001). Educational administration: Theory, research, and practice. New York: McGraw-Hill Companies, Incl.

Murniati, A. R., \& Nasir Usman, M. P. (2009). Implementasi manajemen stratejik dalam pemberdayaan sekolah menengah kejuruan. Perdana Publishing.

Pope-Davis, D. B., Toporek, R. L., \& OrtegaVillalobos, L. (2003). Assessing supervisors' and supervisees' perceptions of multicultural competence in supervision using the Multicultural Supervision Inventory.

Rahayu, F. A. (2016). Hubungan Kepemimpinan Kepala Sekolah Dengan Motivasi Kerja Guru Pada PAUD/KB TK Islam 'Aqila Di Samarinda.
Rivai, V., \& Murni, S. (2016). Education management: analisis teori dan praktik.

Robbins, S., De Cenzo, D., Coulter, M., \& Woods, M. (2013). Management: the essentials. Pearson Higher Education AU.

Sabandi, A., Anisah, A., \& Rusdinal, R. (2018). Training Needs Analysis: Study on Development of School Administration's Competence. Journal Of Educational Review and Research, 1(1), 15-24.

Salim, N. A. (2017). Peningkatan efektivitas pengelolaan sekolah melalui penguatan kemampuan manajerial kepala sekolah. Jurnal Manajemen Dan Supervisi Pendidikan, 2(1).

Sandberg, J. (2000). Understanding human competence at work: An interpretative approach. Academy of Management Journal, 43(1), 9-25.

Sherehiy, B., Karwowski, W., \& Layer, J. K. (2007). A review of enterprise agility: Concepts, frameworks, and attributes. International Journal of Industrial Ergonomics, 37(5), 445-460.

Sodiqin, H., \& Nurdin, D. (2017). Kemampuan manajerial kepala madrasah dan kinerja mengajar guru dalam mutu pendidikan. Jurnal Administrasi Pendidikan, 23(2).

Spencer, L. M., \& Spencer, P. S. M. (2008). Competence at Work models for superior performance. John Wiley \& Sons.

Stoltenberg, C. D. (2005). Enhancing professional competence through developmental approaches to supervision. American Psychologist, 60(8), 857.

Sugiyono, D. (2010). Metode penelitian kuantitatif kualitatif dan R\&D. Penerbit Alfabeta.

Tanjung, M. A., Azmi, F., \& Siahaan, S. (2017). Headmaster policy of senior Islamic school to increas teacher 
professionalism at State Senior Islamic School 2 Model Me. International Journal on Language, Research and Education Studies, 1(1), 130-147.

Usman, H. (2009). Manajemen: Teori, Praktik dan Riset Pendidikan.

Veithzal, R., \& Murni, S. (2009). Education Management Analisis Teori dan Praktik. Jakarta: PT. RajaGrafindo Persada.
Wahyudi, D. (2009). Kepemimpinan Kepala Sekolah Dalam Organisasi Pembelajar (Learning Organization). Alfabeta: Bandung.

Winterton, J., \& Winterton, R. (2002). Developing managerial competence. Routledge.

Zwell, M. (2000). Creating a culture of competence. Wiley. 